\title{
The beaver (Mammalia, Castoridae) from the Miocene of Sandelzhausen (southern Germany)
}

\author{
Clara Stefen
}

Received: 30 July 2006/Accepted: 22 February 2007/Published online: 12 February 2009

(C) Springer-Verlag 2009

\begin{abstract}
The Early/Middle Miocene boundary locality Sandelzhausen (MN5, southern Germany) yielded three beaver teeth: one lower incisor fragment and two strongly worn upper premolars, a right and a left one. The latter are so similar in wear, height, size, and enamel pattern that they probably represent one individual. Although the teeth have been referred to Chalicomys jaegeri Kaup, 1832 (e.g., Hugueney 1999, Fahlbusch 2003), it seems more likely that they belong to Steneofiber depereti Mayet, 1908. However, the assignment of the present material to either one of these species is difficult, because in the advanced wear stage some diagnostic characteristics cannot be assessed. As to ecological implications for the locality Sandelzhausen the taxonomic identity of these two beaver species may not be important. Both are known from riverine, lacustrine or swamp sediments, and it can be assumed that they usually lived in close vicinity to water. Thus, the presence of beaver remains supports the presence of water at Sandelzhausen. However, the teeth might have an allochthonous origin from creeks of the rising Alps.
\end{abstract}

Keywords Rodentia - Castoridae - Sandelzhausen · Miocene - Teeth

Kurzfassung Aus der Fundstelle Sandelzhausen (Grenzbereich Unter-/Mittelmiozän, MN5, Süddeutschland) sind drei Biberzähne bekannt, ein unteres Incisivfragment und zwei stark abgenutzte obere Prämolaren, ein rechter und ein linker. Letztere sind so ähnlich in Größe, Occlusalmuster

\section{Stefen $(\bowtie)$}

Senckenberg Naturhistorische Sammlungen Dresden,

Museum für Tierkunde Dresden, Königsbrücker Landstraße 159,

01109 Dresden, Germany

e-mail: cmstefen@web.de und Abnutzungsgrad, dass anzunehmen ist, dass sie von einem Individuum stammen. Obwohl diese Zähne zu Chalicomys jaegeri (Kaup, (1832)) gestellt worden sind [z.B. Hugueney (1999), Fahlbusch (2003)], erscheint es wahrscheinlicher, dass sie zu Steneofiber depereti Mayet, (1908) gehören. Aber eine genaue taxonomische Zuordnung der Zähne zu einer der beiden Arten ist schwierig, weil in dem Abnutzungsgrad bestimmte diagnostische Merkmale nicht mehr zu sehen sind. Für die ökologische Interpretation von Sandelzhausen mag es egal sein, welche Biberart vorkommt. Beide sind von Fluss-, See- oder Sumpfsedimenten bekannt und implizieren das Vorhandensein von Wasser in Sandelzhausen. Es kann aber auch sein, dass die Biberzähne allochthoner Herkunft sind und dass sie aus Bächen der sich hebenden Alpen stammen.

Schlüsselwörter Rodentia - Castoridae - Sandelzhausen · Miocene - Zähne

\section{Introduction}

The fossil locality Sandelzhausen in the Molasse Basin of southwest Germany has been excavated in several campaigns from 1969 to 1975 and 1994 to 2001, which have been well documented (Fahlbusch 2003). More than 50,000 determinable specimens were found in Sandelzhausen and thus the fauna of the locality and surrounding area is well preserved. Sandelzhausen is placed in the Neogene mammal biozone MN5 (Fahlbusch 2003). Based on recent bio-, litho-, and magnetostratigraphic investigations the stratigraphic position of the locality Sandelzhausen is situated at or very close to the Early/Middle Miocene boundary (Karpatian/Badenian boundary) (Moser et al. 2009 this volume). Although thousands of micromammal teeth were 
recovered from Sandelzhausen, hardly any beaver material has emerged.

\section{Materials and methods}

Only three beaver teeth were recovered from Sandelzhausen; all are housed in the Bayerische Staatssammlung für Paläontologie und Geologie, München (BSPG) under the inventory numbers BSPG 1959 II 2512-2514. In the following text the prefix of the inventory number is deleted: 2514 right lower incisor fragment; 2513, right upper fourth premolar (P4 sup. dext.); 2512, left upper fourth premolar (P4 sup. sin.). The nomenclature of the description of the morphology of the teeth follows Stirton (1935). Shape and size of cheek teeth of beavers change from the top to the base of the crown (Crusafont Pairó and Truyols Santonja 1948, Stefen 1997), thus measurements are usually taken at the occlusal surface, but in some comparative material additionally at the base of the crown (in Fig. 2 indicated by "basal").

\section{Systematic paleontology}

Class Rodentia Bowdich, 1821

Family Castoridae Gray, 1821

Genus Steneofiber Geoffroy, 1833

Type species: Steneofiber castorinus Pomel, 1847, Lower Miocene, France.

Steneofiber depereti Mayet, 1908

Brief synonymy according to Hugueney (1999):

1908 Steneofiber depereti Mayet: 206-209, pl. 9 figs. 1, $2 \mathrm{a}-\mathrm{b}$

1884 Steneofiber (Chalicomys) jaegeri Kaup. -Schlosser: 23-24, pl. 6 figs. 1, 4, 5, 6, 10-14, 18, 24, 27

1925 Steneofiber jaegeri Kaup. -Stehlin: 23-27

1935 "Steneofiber" depereti Mayet. -Stirton: 400

1938 Steneofiber jaegeri Kaup. -Seemann: 39-42, pl. 1 figs. 6-9

non 1948 Steneofiber depereti Mayet. -Crusafont and Truyols Santonja: 47-68

non 1994 Steneofiber hesperus Douglas. -Xu: 85

\section{Description and discussion}

The incisor fragment (2514) represents the anterior tip of a lower right incisor. It is triangular in cross section, missing the medial (opposite to the enamel face) part. The enamel face is very slightly convex and the enamel is smooth. Width across enamel face: $7.35 \mathrm{~mm}$.

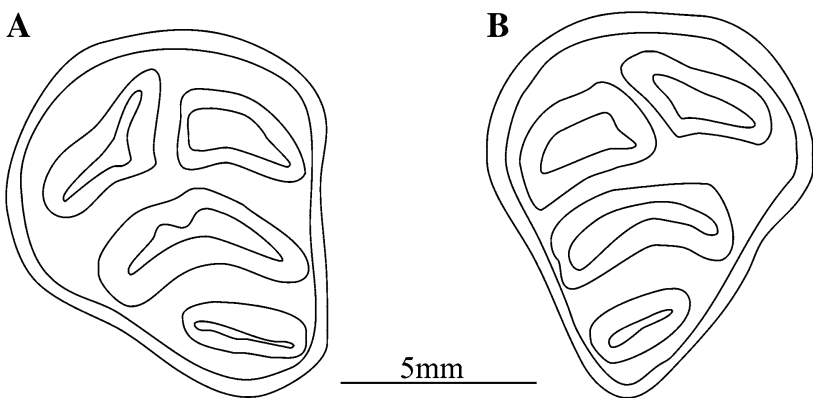

Fig. 1 Occlusal view of upper premolars (P4) of $S$. depereti from Sandelzhausen (MN5). a Right premolar, b left premolar. Scale bar $5 \mathrm{~mm}$

The two upper premolars (2512 and 2513, P4 sup. sin. and dext., respectively) are strongly worn and elongated triangular in outline (Fig. 1). Measurements: specimen 2512: length $9.95 \mathrm{~mm}$ and width $9.11 \mathrm{~mm}$ at chewing surface, height $6.72 \mathrm{~mm}$; specimen 2513: length $9.7 \mathrm{~mm}$ and width $9.30 \mathrm{~mm}$ at chewing surface, height $6.24 \mathrm{~mm}$. All fossettes, including the hypofossettes, are closed. The hypofossette and parafossette are directly opposite to each other (sometimes called "face to face"), both taking up about the same amount of space on the chewing surface. The mesofossette is convexly curved and the metafossette fills the distal part of the tooth. As the two premolars are extremely similar in size and wear, it can be assumed that they represent one individual. It is likely that the incisor is also from the same individual as it also was found very close by (Fahlbusch, oral communication 2005), but of course there are no direct clues.

The teeth from Sandelzhausen have been referred to Chalicomys jaegeri (Hugueney 1999). However, it seems more likely that they belong to Steneofiber depereti. There are several reasons for this changed assignment. First, the slightly convex enamel face of the incisor [lower incisors in C. jaegeri have a truly flat and straight enamel face (Aldana Carrasco 1992)]; second, the strongly triangular outline of the chewing surface of the premolars, which is more typical for $S$. depereti. Especially with wear the upper premolars tend to be elongated triangular in this species. Third, the closed hypofossettes should not close with wear in typical C. jaegeri. Additionally, the size of the strongly worn premolars is very similar to strongly worn teeth of contemporaneous $S$. depereti from Hambach 6C (Germany, MN5) (Fig. 2). Unfortunately, there are no data on upper premolars from $S$. depereti available, e.g., from Artenay (France, MN4a) or Baigneaux-en-Beauce (France, MN5) for comparisons. There are two features characteristic of C. jaegeri, which cannot be assessed at the present wear stage of the teeth: the cement filling of the striae, and the well-developed and long striae opposite to the hypostriae.

During the Miocene at least two evolutionary lineages of beavers have been recognized in Europe: 


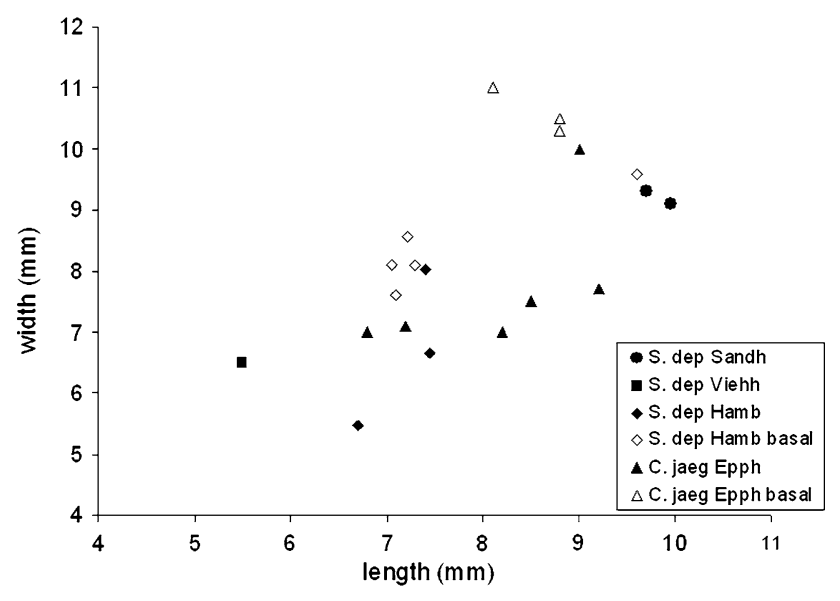

Fig. 2 Length/width scatter diagram $(\mathrm{mm})$ of premolars (P4) of $S$. depereti from Sandelzhausen (Sandh) (MN5) in comparison with $S$. depereti from Hambach 6C (Hamb), from Viehhausen (Viehh) and Chalicomys jaegeri from the type locality Eppelsheim (Epph). Data are from: Seemann 1938: Viehhausen (MN5); Stefen unpublished data: Eppelsheim (MN9). "Basal" refers to tooth measurement at the base of the crown; strongly worn teeth are best compared with basal measurements of less worn teeth

Steneofiber-Chalicomys (Schreuder 1929, 1931; Stefen 1997) and Steneofiber-Trogontherium (Mayhew 1978) and thus Chalicomys jaegeri can be considered the successor of S. depereti (Ginsburg 1971). In both lineages hypsodonty and the persistence or length of striae/iids opposite to the hypostria/iid increased. C. jaegeri from the type locality Eppelsheim (Germany, MN9) is characterized by three features: hypostriids extending to the base of the cheek teeth, three well-expressed striids on the lingual side, and marked cement filling in the synclines (Kaup 1832: pl. 26 figs. 1-4; Hugueney 1999: 288). Already in beaver populations of MN5 age there are individual teeth that show elongated hypostriids (e.g., in Hambach 6C; and Eggingen-Mittelhart: Stefen 1997: text-fig. 39b). Thus the distinction of transitional forms between Steneofiber and Chalicomys may be very difficult to refer to one of these genera, especially when strongly worn. Additionally the sample of preserved maxillary teeth of $C$. jaegeri from Eppelsheim is limited so that the whole range of variability is hard to assess. From the analysis of $S$. depereti from Hambach 6C (MN5) in detailed comparison with the contemporaneous beaver material, it seems unlikely that the highly evolved beaver Chalicomys jaegeri existed in Europe during the time interval from MN4 to MN6. Thus the age of the beaver from Sandelzhausen is most consistent with $S$. depereti.

\section{Conclusions}

Considering the ecological implications for the locality Sandelzhausen, it may not even be of great importance whether the beaver was Chalicomys jaegeri or Steneofiber depereti. S. depereti is supposed to have been associated with a semiaquatic lifestyle and life strategy, similar to recent Castor (Hugueney \& Escuillié 1995). For Chalicomys a semiaquatic lifestyle has never been shown in the same way, but as most finds are from riverine or swamp sediments, it can be assumed that it also lived in close vicinity to water. Thus the beaver remains support the presence of water, possibly a meandering stream or oxbow lake, at Sandelzhausen. The question of why only three beaver teeth have been found in such a habitat probably favorable to beavers remains unanswered. The teeth might have an allochthonous origin in creeks further upstream, and were subsequently deposited in Sandelzhausen in a brief but severe flood, which left no traces of prolonged transportation. Beavers in general might have been rare at that time, as beavers are often represented by few teeth in one locality only. Also, their preferred habitat could have been more specific types of water bodies than for modern beavers, such as extreme swamps or waters with other as yet unknown qualities not present in Sandelzhausen.

Acknowledgments I want to thank V. Fahlbusch (Munich) for asking me to work on the beaver from Sandelzhausen and G. Rössner (Munich) for organizing the Sandelzhausen Symposium in 2005, which was financed by the Deutsche Forschungsgemeinschaft. The comments of the reviewers L. Flynn (Cambridge, MA, USA), who also corrected the English, and L. Maul (Weimar) are kindly acknowledged. The Deutsche Forschungsgemeinschaft (DFG) provided funding to attend the Sandelzhausen Symposium 2005 in Mainburg (GZ-4850/88/05).

\section{References}

Aldana Carrasco, E.J. 1992. Los Castoridae (Rodentia, Mammalia) del Neõgeneo de Cataluna (España). Treballs del Museu de Geologia de Barcelona 2: 99-141.

Bowdich, T. E. 1821. An analysis of the natural classifications of Mammalia for the use of students and travellers. p 115. Paris: J. Smith.

Crusafont Pairó, M., and J. Truyols Santonja. 1948. Sobre el descubrimiento de un nuevo yacimiento del meotico en el Vallés. Bolle Inst Geol Min España 60:71-107.

Fahlbusch, V. 2003. Die miozäne Fossil-Lagerstätte Sandelzhausen. Die Ausgrabungen 1994-2001. Zitteliana A 43:109-212.

Gray, J.E. 1821. On the natural arrangement of vertebrose animals. London Medical Repository 15(1):296-310.

Geoffroy Saint-Hilaire, E.-F. 1833. Considérations sur des ossements fossiles la plupart inconnus, trouvés et observés dans les bassins de l'Auvergne. Revue encyclopédique (Paris) 59:76-95.

Ginsburg, L. 1971. Sur l'évolution des Steneofiber (Mammalia, Rodentia) en France. Comptes Rendus Académie des Sciences, Paris, 273, Série D:2159-2161.

Hugueney, M. 1999. Family Castoridae. In The Miocene land mammals of Europe, ed. G.E. Rössner, and K. Heissig, 281300. München: Friedrich Pfeil Verlag.

Hugueney, M., and F. Escuillié. 1995. K-strategy and adaptive specialization in Steneofiber from Montaigu-le-Blin (dept. Allier, France; Lower Miocene, MN 2a $\pm 23 \mathrm{Ma}$ ): first evidence of 
fossil life-history strategies in castorid rodents. Palaeogeography, Palaeoclimatology, Palaeoecology 113:217-225.

Kaup, J.J. 1832. Beschreibung dreier Gattungen urweltlicher Nager des zoologischen Museums zu Darmstadt, welche von den jetzt lebenden Genera verschieden sind. Isis (Leipzig) 1832(9):992995

Mayet, L. 1908. Étude des Mammifères Miocènes des sables de 1'Orléanais et des faluns de la Touraine. Annales de L'Université de Lyon Nouvelle Serie I. Sciences. Médicine 24:1-336.

Mayhew, D.F. 1978. Reinterpretation of the extinct beaver Trogontherium (Mammalia, Rodentia). Philosophical Transactions of the Royal Society London B 281(983):407-438.

Moser, M., Rössner, G.E., Göhlich, U.B., Böhme, M., Fahlbusch, V. 2009, this volume. The fossil lagerstätte Sandelzhausen (Miocene; southern Germany): history of investigation, geology, fauna and age. In: Rössner, G.E. \& Göhlich, U.B.: Fossil lagerstätte Sandelzhausen (Miocene, southern Germany): Contributions to the fauna. Paläontologische Zeitschrift 83(1):this volume.

Pomel, A. 1847. Note sur des animaux fossiles découverts dans le département de 1'Allier (addition au Mémoire sur la géologie paléontologie etc. Bull 2ème Ser. T 3, p 353. Bulletin de la Societe géologique de France T 4, p 378.

Schlosser, M. 1884. Die Nager des europäischen Tertiärs nebst Betrachtungen über die Organisation und die geschichtliche
Entwicklung der Nager überhaupt. Palaeontographica 31:19162.

Schreuder, A. 1929. Conodontes (Trogontherium) and Castor from the Teglian Clay compared with the Castoridae from other localities. Archives du Musée Teyler Ser. III VI:99-321.

Schreuder, A. 1931. Conodontes, Trogontherium and the other Castoridae. Paläontologische Zeitschrift 13:148-176.

Seemann, I. 1938. Die Insektenfresser, Fledermäuse und Nager aus der Obermiozänen Braunkohle von Viehhausen bei Regensburg. Palaeontographica A 89:1-56.

Stefen, C. 1997. Steneofiber eseri (Castoridae, Mammalia) von der Westtangente bei Ulm im Vergleich zu anderen Biberpopulationen. Stuttgarter Beiträge zur Naturkunde 255:1-78.

Stehlin, H.G. 1925. catalogue des Ossements de Mammifères Tertiaires de la Collection Bourgeois à l'ecole de Pont-Levoy (Loir et Cher, France). Bull de la Société d'Histoire Naturelle et d'Anthropologie du Loir-et-Cher 18:77-277.

Stirton, R.A. 1935. A review of tertiary beavers. University of California Publications in Geological Sciences 23(13):391-458.

$\mathrm{Xu}$, X.F. 1994. Evolution of Chinese Castoridae. In Rodent and lagomorph families of Asian origins and diversification, eds. Tomida, Y., Li, C.K., Setoguchi, T., 8:77-97. Tokyo: National Science Musuem Monographs. 